\title{
Grand Challenges: Refugees and Conflict
}

\author{
Jane Freedman * \\ CRESPPA-GTM, Université Paris 8, Saint-Denis, France
}

Keywords: refugees, forced migration, displacement, borders, conflict, violence, gender, international politics

\section{OPEN ACCESS}

Edited and reviewed by:

Evangelia Tastsoglou,

Saint Mary's University, Canada

*Correspondence:

Jane Freedman

jane.freedman@cnrs.fr

Specialty section:

This article was submitted to

Refugees and Conflict,

a section of the journal

Frontiers in Human Dynamics

Received: 24 September 2019

Accepted: 15 October 2019

Published: 30 October 2019

Citation:

Freedman J (2019) Grand Challenges: Refugees and Conflict.

Front. Hum. Dyn. 1:1

doi: 10.3389/fhumd.2019.00001
In 2019 UNHCR announced that the number of people displaced in the world had reached the highest number ever at 70.8 million $^{1}$. Causes of displacement are multiple and complex -armed conflicts, persecution and discrimination (including gender-based forms of violence), structural violence and inequality. The conflict in Syria has by itself led to the forced displacement of over ten million people, of whom over four million have crossed borders into neighboring countries (Martin, 2016). And whilst the number of people forced to move from their homes increases, the responses to displacement both national and international are still not sufficient to offer protection and security to refugees. Many of the world's wealthier countries are in the process of building walls and reinforcing border security to attempt to prevent refugees from reaching their territory. However, the vast majority of refugees remain in poorer countries, either in massive refugee camps, or struggling to survive in urban centers and their peripheries.

Recent research has advanced our understanding of the causes of forced displacement and the experiences of refugees, and in doing so has questioned the utility of the categorizations imposed by international law and politics, which for example, divide refugees from economic migrants, and distinguish between forced and voluntary migration (Allen et al., 2018; Crawley and Skleparis, 2018). This questioning of categories opens up interesting definitional questions: who is a refugee? Are existing international laws and conventions sufficient to offer protection? Or do they need to be adapted to changing geopolitical realities? The impacts of climate change on migration, for example, has led to a debate over whether a new group of "climate refugees" should be recognized under international law (Gemenne, 2015)? These debates on categorization and definitions add to existing critiques of international refugee conventions and policies, which have pointed to the ways in which these exclude groups such as victims of gender-based forms of persecution (Freedman, 2015).

Widespread images of people trying to cross newly built walls and fences at international borders, or being rescued from sinking ships as they attempt to cross sea borders, have brought into stark relief the impacts of the increasing securitization of migration across the world. Securitization of migration and closing of borders has led to increasing violence and insecurities for refugees themselves, without having any real impact on decreasing migration flows (Andersson, 2015). Refugees are being forced into taking increasingly expensive and dangerous routes to reach their countries of destination, and many are dying on the route (Kovras and Robins, 2016; Bejarano, 2017). And these experiences of violence and insecurity vary according to the social, economic and political structures of inequality in countries of origin, transit and destination. We need to understand more the ways in which securitization has a direct impact on the experiences of individuals and the ways that gendered and racialized forms of insecurity are manifested during refugee journeys (Freedman, 2016). For those refugees who survive these dangerous journeys, conditions of reception in countries of destination are also often inadequate. Recent reports have highlighted the insalubrious and dangerous conditions for refugees living in hotspots on the Greek

${ }^{1}$ https://www.unhcr.org/figures-at-a-glance.html 
islands for example. Many refugees now find themselves trapped in dirty and overcrowded camps as a result of the EU-Turkey agreement of March 2016 and of the reluctance of other EU Member States to relocate some of these refugees and settle them in their own countries.

And whilst much attention has focused on the so-called refugee "crises" in Europe and other rich countries, we must remember that the majority of the world's refugees still live in the global South, frequently in countries bordering their own. Too little attention is being paid to the ways in which these poorer countries are impacted by hosting refugees, and what the refugees' experiences are within these countries, whether in camps or as urban refugees.

The Global Compact on Refugees ${ }^{2}$ a new international agreement on refugees signed in 2018 was announced by the international community as a way forward for "sharing responsibility" for refugee protection and has been hailed by some as a welcome advance. However, critics have pointed to the fact that the Compact, despite its promise to pay more attention to the "root causes" of refugee flows, and to encourage all States to share responsibility for protection, might actually prove a step backwards as it may dilute the international principles of refugee law, and weaken protection of women and children (Chimni, 2018). Further research is necessary to understand what if any impact this new Compact might have, and whether richer States will in fact agree to share greater responsibility for protection of refugees with the nations which currently host large refugee populations. The fact that the Compact is a non-binding agreement, with no concrete measures for responsibility sharing seems to indicate that current policies of securitization of borders and refoulement of refugees by the US, European Union Member States and other richer countries will continue.

Restrictive policies on refugee movement have fuelled and been fuelled by various public and media representations of these refugees as some kind of "threat" to host countries and/or "undeserving" of support (Szczepanik, 2016; Holzberg et al., 2018). These media representations and the impacts that they

\footnotetext{
${ }^{2}$ Global Compact on Refugees, UN doc A/73/12 (Part II) (2 August 2018); Global Compact for Safe, Orderly and Regular Migration, UN doc A/RES/73/195 (19 December 2018).
}

have both on public opinion and on policymaking on refugees is a subject that merits further research and analysis. The ubiquity of discourses representing refugees as a threat might indicate that public opinion is in favor of more restrictive policies to prevent refugees from arriving in host countries. But this perception should be nuanced with a consideration of the various solidarity movements with refugees which have developed and strengthened, including initiatives to rescue refugees from the Mediterranean, to provide accommodation and food, or other forms of solidarity and protest against exclusionary politics (Ataç, 2016; Stierl, 2016). Solidarity can help to support inclusion and integration of refugees into host societies and these solidarity movements might also be seen to help refugees to exercise their agency and to recreate new forms of citizenship.

It is vital that research on issues related to refugees not consider these refugees merely as "victims" of violence and conflict and displacement but takes into account their agency as actors. How do refugees themselves see their situation, and how do they plan their strategies both for flight and for integration into new societies? These are among the many questions and pressing challenges with which research should be concerned. And across all of these questions and issues, researchers should take an approach which highlights differences of gender, sexual orientation, class, ethnicity, race, nationality, age, ability, and so on, to ensure that neither refugees, nor host communities are considered as homogeneous and monolithic, and that the impacts of all of these socially constructed differences on the experience of displacement and migration are fully considered. It is clear that numbers of refugees will not diminish significantly in the near future, so we must be concerned with answering these questions and to provide recommendations and solutions that will ensure better protection for those impacted by displacement, and reduce the insecurities and violence faced by refugees across the world.

\section{AUTHOR CONTRIBUTIONS}

The author confirms being the sole contributor of this work and has approved it for publication.

Bejarano, C. (2017). Fear, vulnerability, and death for children and youth at the US-Mexico Border. Conflict Violence Peace. 11, 369-385. doi: 10.1007/978-981-287-038-4_10

Chimni, B. S. (2018). Global compact on refugees: one step forward, two steps back. Int. J. Refugee Law 30, 630-634. doi: 10.1093/ijrl/eey067

Crawley, H., and Skleparis, D. (2018). Refugees, migrants, neither, both: categorical fetishism and the politics of bounding in Europe's 'migration crisis'. J. Ethnic Migr. Stud. 44, 48-64. doi: 10.1080/1369183X.2017.1348224

Freedman, J. (2015). Gendering the International Asylum and Refugee Debate. Basingstoke: Palgrave Macmillan. doi: 10.1057/9781137456236

Freedman, J. (2016). Engendering security at the borders of Europe: women migrants and the Mediterranean 'crisis'. J. Refugee Stud. 29, 568-582. doi: $10.1093 /$ jrs/few019

Gemenne, F. (2015). One good reason to speak of 'climate refugees'. Forced Migr. Rev. 49, 70-71. Available online at: https://www.fmreview.org/sites/fmr/files/ 
FMRdownloads/en/climatechange-disasters/gemenne.pdf (accessed October 21, 2019).

Holzberg, B., Kolbe, K., and Zaborowski, R. (2018). Figures of crisis: the delineation of (un) deserving refugees in the German media. Sociology. 52, 534-550. doi: $10.1177 / 0038038518759460$

Kovras, I., and Robins, S. (2016). Death as the border: managing missing migrants and unidentified bodies at the EU's Mediterranean frontier. Polit. Geogr. 55, 40-49. doi: 10.1016/j.polgeo.2016.05.003

Martin, S. F. (2016). The global refugee crisis. Georgetown J. Int. Affairs. 17, 5-11. doi: 10.1353/gia.2016.0000

Stierl, M. (2016). A sea of struggle - activist border interventions in the Mediterranean Sea. Citizensh. Stud. 20, 561-578. doi: 10.1080/13621025.2016.1182683
Szczepanik, M. (2016). The 'good' and 'bad' refugees? Imagined refugeehood (s) in the media coverage of the migration crisis. J. Identity Migr. Stud. 10, 23-33.

Conflict of Interest: The author declares that the research was conducted in the absence of any commercial or financial relationships that could be construed as a potential conflict of interest.

Copyright $\odot 2019$ Freedman. This is an open-access article distributed under the terms of the Creative Commons Attribution License (CC BY). The use, distribution or reproduction in other forums is permitted, provided the original author(s) and the copyright owner(s) are credited and that the original publication in this journal is cited, in accordance with accepted academic practice. No use, distribution or reproduction is permitted which does not comply with these terms. 